\title{
Determination of Prospective Chemistry Teachers' Cognitive Structures and Misconceptions About Stereochemistry
}

\author{
Mustafa Durmaz \\ Correspondence: Mustafa Durmaz, Necmettin Erbakan University, Ahmet Kelesoglu Faculty of Education, Department \\ of Mathematics and Science Education, 42090, Meram, Konya, Turkey.
}

Received: June 11, 2018

doi:10.11114/jets.v6i9.3353
Accepted: June 29, $2018 \quad$ Online Published: July 3, 2018

URL: https://doi.org/10.11114/jets.v6i9.3353

\begin{abstract}
The purpose of this study was to investigate the cognitive structures of chemistry teacher candidates about "stereochemistry". A case study research method, one of the qualitative research patterns, was used in the study and the sample of study involved 28 prospective chemistry teachers who had taken Organic Chemistry I and II courses at Education Faculty of a middle Anatolian university. For the data collection, stereochemistry concept inventory comprising of 20 questions was used. In the analysis of data, students' responses in SCI were categorized. The detailed analysis of the results indicated that chemistry teacher candidates had some misconceptions concerning stereochemistry parallel to the literature. Based on these observations, some suggestions were presented for improving students' foundational understanding about stereochemistry.
\end{abstract}

Keywords: organic chemistry, stereochemistry, chemistry education research, chemistry teacher candidates

\section{Introduction}

Learning basic concepts in organic chemistry is very important since these concepts are essential for further understanding of other notions that are related to a higher level (Şendur, Toprak \& Pekmez, 2011). Stereochemistry which is defined as the field of chemistry that deals with the structures of molecules in three dimensions (Bruice, 2016) is a good example for this reality. Stereochemistry has been accepted as difficult to understand (Barta \& Stille, 1994; Black, 1990) since it requires the use of specific stereochemical terms, visualizing structures in three dimensions and interconverting between different formula/structures and projection. For this reason, the number of articles dealing with education of stereochemical topics has been increased in recent years. Examples include articles on methods for assigning stereochemical configurations (Eliel, 1985), representations of organic molecules (Pavlinic et al., 2001; Stull et al., 2016), rectification of difficulties concerning 3D dimensional structures, rotation and reflection use of 3D visualisation ability (Tuckey, Selvaratnam, \& Bradley, 1991; Mohamed-Salah \& Alain, 2016; Knowles, 2017), teaching stereochemistry with programmed instruction (Kurbanoglu, Taskesenligil \& Sozbilir, 2006), web-based and student-centered stereochemistry tutorials (Burrmann \& Moore 2013 and 2015), a stereogame for reviewing stereochemistry concepts (da Silva Junior et al., 2017).

It is clear that stereochemistry and related subjects are included in chemistry and biology curricula in high school programmes in Turkey (Table 1). The fact that the topic also involves organic compounds found in living organisms such as carbohydrates and proteins shows the interdisciplinary property of stereochemistry. As in all other subjects of organic chemistry, prospective teachers' cognitive structures in stereochemistry is very important. In higher education; concepts of stereoisomerism, 3D structures, optical activity, nomenclature of chiral compounds and chirality are taught not only in disciplines of organic chemistry but also courses in biology, pharmacy, biochemistry, biotechnology and molecular biology. Moreover, a comprehensive understanding of the interaction between a drug molecule and a receptor or enzyme active site is based upon accurate stereochemical details. 
Table 1. Stereochemistry and related subjects in chemistry and biology curricula in high school programmes in Turkey

\begin{tabular}{c|l|l}
\hline Grade level & Course & \multicolumn{1}{c}{ Subject } \\
\hline & & Organic compounds \\
& & Energy in living organisms (Carbohydrates, proteins) \\
& Functional groups \\
& & Isomerism in organic compounds \\
$10^{\text {th }}$ and $12^{\text {th }}$ grades & Chemistry & Geometric (cis-trans) isomerism \\
& & Optical isomerism \\
& & R/S nomenclature \\
& & Biomolecules (Carbohydrates, proteins, polysaccharides) \\
\hline $9^{\text {th }}$ grade & Biology & Organic compounds found in living organisms (Carbohydrates, proteins) \\
\hline
\end{tabular}

Conceptual understanding of abstract concepts is important for making sense of knowledge. By this way, students can transfer their learning experiences from one problem to another or into new situations they encounter (Colley, 2006; Taber, 2000). One of the most important factor that hinders conceptual understanding and transfer of learning in natural sciences is misconceptions (Nakhleh, 1992; Schmidt, 1997; Michael 2002; Vrabec \& Proksa, 2016; Woolley et al., 2018). Misconceptions are developed by students erroneously and they are inconsistent with current scientifically accepted concepts (Köse, 2008). There are different types of methods such as open-ended questions (Canpolat, 2006), three-tier tests (Milenkovic et al., 2016), concept mapping (Hazel \& Prosser, 1994), drawings (Köse, 2008) and interviews (Şendur, 2012; Gercek, 2018) for detecting misconceptions in students of various levels. In the literature, although in a number of studies misconceptions have been reported in organic chemistry (Taagepera \& Noori, 2000; Taber, 2002; Bryan, 2007; Anderson \& Bodner, 2008; Domin, Al-Masum \& Mensah 2008; Ferguson \& Bodner, 2008), misconceptions related to subdomain of stereochemistry are very limited (Krylova, 1997; Lyon, 1999; Rushton et al., 2008, Mdachi, 2012).

For these reasons, it was aimed to determine levels of understanding of prospective chemistry teachers relating to all topics of stereochemistry and misconceptions by use of stereochemistry concept inventory in this study. For this purpose, following questions were tried to be answered:

1. What are the understanding levels of prospective chemistry teachers about stereochemistry?

2. What are the prospective chemistry teachers' misconceptions regarding stereochemistry?

\section{Methodology}

\subsection{Research Sample}

The sample of the study was composed of 28 prospective chemistry teachers ( 23 female and 5 male) including all third and fourth year students $(N=28)$ who had taken Organic Chemistry II course at the Department of Chemistry Education of Necmettin Erbakan University in 2016-2017 and 2017-2018 academic years. Population by gender was as follows: $18 \%$ males and $82 \%$ females. The students were in the range of 20-22 age. The research group had accepted to voluntarily participate in the study. According to the curriculum, the teaching topic stereochemistry is studied within the course of Organic Chemistry II. This course is taught in the sixth semester (4 hours per week and 14 weeks in a semester) $56 \mathrm{~h}$ of lectures.

\subsection{Data Collection Tools}

This study is a qualitative research aiming to determine prospective chemistry teachers' comprehension levels and misconceptions about stereochemistry. For this purpose, stereochemistry concept inventory developed by Leontyev (2015) was used as data collection tool. The stereochemistry concept test comprising of 20 questions was translated to Turkish by the researcher and administered to students for 25 minutes. Correct or incorrect markings were required from students. Each question has only one correct answer and two or three distractors. All tests were carefully reviewed and the results entered into Microsoft Office Excel.

\section{Results and Discussion}

The answers given by prospective chemistry teachers to the stereochemistry concept inventory (SCI) were classified as correct, wrong and blank and given in Table 2. The topics given in Table 2 were already defined by Leontyev in his doctoral dissertation. 
Table 2. Distribution of frequencies and percentages of the students' answers

\begin{tabular}{cccccccc}
\hline & & \multicolumn{2}{c}{ Correct } & \multicolumn{2}{c}{ Wrong } & \multicolumn{2}{c}{ Blank } \\
\hline Topic & Question No & f & $\%$ & f & $\%$ & f & $\%$ \\
\hline \multirow{3}{*}{ Chirality } & Q1 & 20 & 71.4 & 8 & 28.6 & --- & --- \\
& Q2 & 7 & 25.0 & 21 & 75.0 & --- & --- \\
& Q3 & 5 & 17.9 & 23 & 82.1 & --- & --- \\
& Q4 & 2 & 7.1 & 26 & 92.9 & --- & --- \\
\hline Stereoisomers & Q5 & 26 & 92.9 & 2 & 7.1 & --- & --- \\
\hline \multirow{2}{*}{ Cahn-Ingold-Prelog rules } & Q6 & 23 & 82.1 & 5 & 17.9 & --- & --- \\
& Q7 & 21 & 75.0 & 7 & 25.0 & --- & --- \\
\hline R, S nomenclature & Q8 & 25 & 89.3 & 2 & 7.1 & 1 & 3.6 \\
& Q9 & 18 & 64.3 & 8 & 28.6 & 2 & 7.1 \\
\hline Stereoisomers/ & Q10 & 13 & 46.4 & 15 & 53.6 & --- & --- \\
Enantiomers & Q11 & 5 & 17.9 & 23 & 82.1 & --- & --- \\
\hline Enantiomers & Q12 & 17 & 60.7 & 11 & 39.3 & --- & --- \\
\hline Stereoisomers/ & Q13 & 21 & 75.0 & 5 & 17.9 & 2 & 7.1 \\
Diastereomers & Q14 & 13 & 46.4 & 15 & 53.6 & --- & --- \\
\hline \multirow{2}{*}{ Meso compounds/ } & Q15 & 7 & 25.0 & 21 & 75.0 & --- & --- \\
Optical activity & Q16 & 7 & 25.0 & 20 & 71.4 & 1 & 3.6 \\
& Q17 & 12 & 42.9 & 15 & 53.6 & 1 & 3.6 \\
\hline \multirow{2}{*}{ Projections } & Q18 & 12 & 42.9 & 15 & 53.6 & 1 & 3.6 \\
& Q19 & 13 & 46.4 & 15 & 53.6 & --- & --- \\
& Q20 & 8 & 28.6 & 18 & 64.3 & 2 & 7.1 \\
\hline
\end{tabular}

As can be seen from Table 2, for chirality topic, most of the students chose scientifically correct answer only for the first question. In this question, it was asked from students to determine achiral molecules. As shown in Figure 1, when the results of questions 2-4 were analyzed in detail, instead of defining chirality as nonsuperimposable mirror images, students generally chose the option representing a misconception. According to this misconception, a molecule had been classified as chiral if it had an atom with four different substituents. From these results it can be concluded that instead thinking a molecule as a whole entity, students generally focus on a tetrahedral carbon atom with four different substituents. From questions 2 and 4, it was also observed that students had problems about realizing a plane of symmetry in molecules they encountered. Because only $25 \%$ and $7.1 \%$ percent of the students answered correctly Q2 and Q4 respectively.

Q2. Is the following molecule chiral?

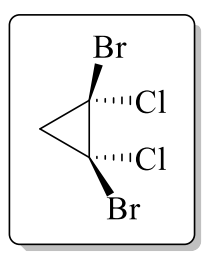

Yes, because its mirror image cannot be overlaid on itself. A Yes, because it has a carbon atom with four different substituents. B No, because it is a racemic compound. C No, because it has a plane of symmetry. D

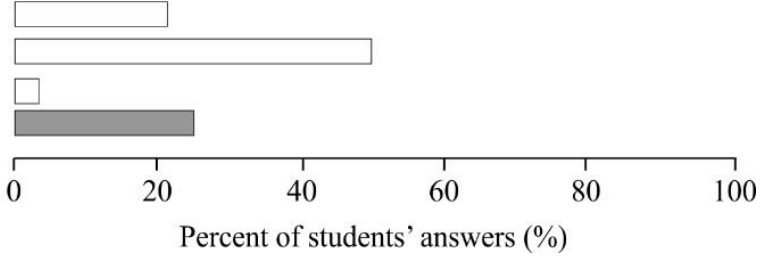

Q3. Which of the following molecules is (are) chiral?

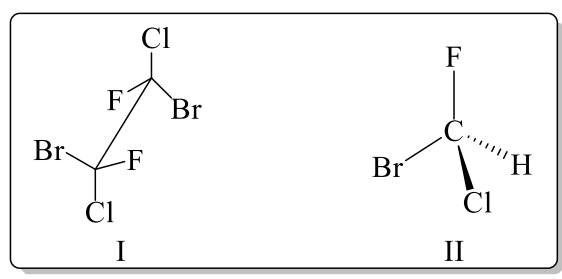

I only. A |

II only. B

I and II. C

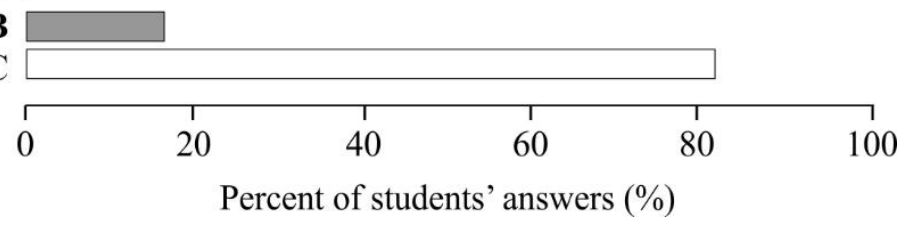


Q4. How many stereocenters exist in the following compound?
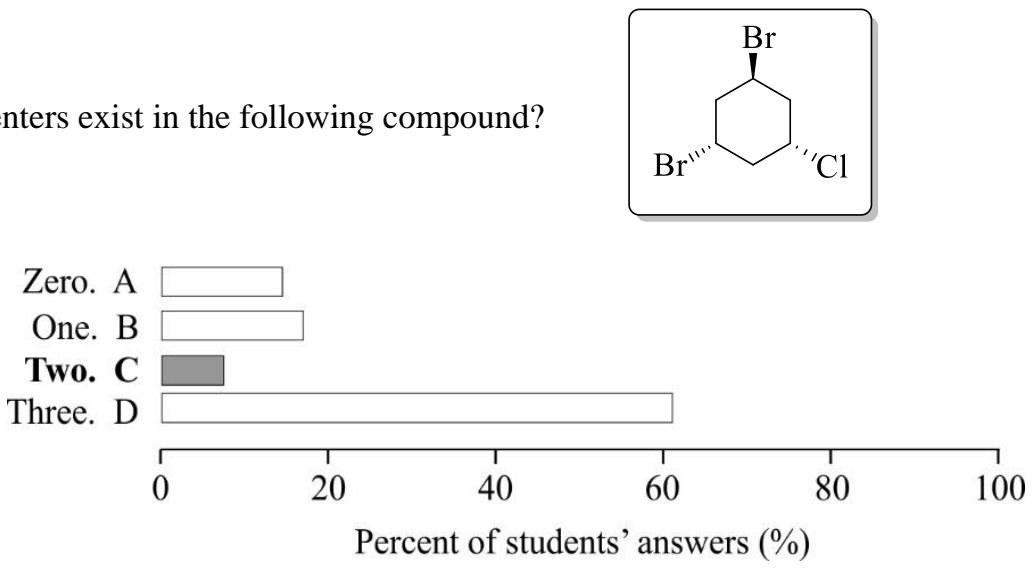

Figure 1. Results of questions 2-4. The correct answers are marked in bold

From the answers given to Q5, it is clear that students had a high level of comprehension about the maximum number of stereoisomers for a compound that had $n$ stereocenters. Because, $92.9 \%$ of all prospective teachers answered this question correctly.

The next two questions (Q6 and Q7) were about the Cahn-Ingold-Prelog rules. 82.1 and $75.0 \%$ of the students determined the priority correctly by ranking substituents according to atomic mass. For Q6 and Q7, 17.9 and $25.0 \%$ of students had a misconception that ranking of the substituents was based on electronegativity or size respectively.

Q8. What are the configuration and relative priority of the substituents at the stereogenic center in the following molecule?

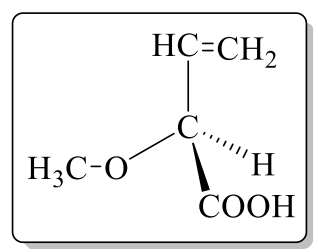

Configuration: $R$; Priority: $\mathrm{HC}=\mathrm{CH}_{2}>\mathrm{COOH}>\mathrm{OCH}_{3}$ A I

Configuration: $R$; Priority: $\mathrm{OCH}_{3}>\mathrm{COOH}>\mathrm{HC}=\mathrm{CH}_{2}$ B

Configuration: $S$; Priority: $\mathrm{OCH}_{3}>\mathrm{COOH}>\mathrm{HC}=\mathrm{CH}_{2} \mathrm{C}$

Configuration: $S$; Priority: $\mathrm{HC}=\mathrm{CH}_{2}>\mathrm{COOH}>\mathrm{OCH}_{3}$ D

No answer

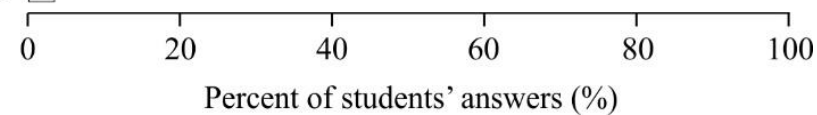

Q9. In the following molecules, substituents are arranged according to their priority, where "1" has the highest priority and " 4 " has the lowest priority. Which of the molecules has an " $\mathrm{R}$ " configuration?

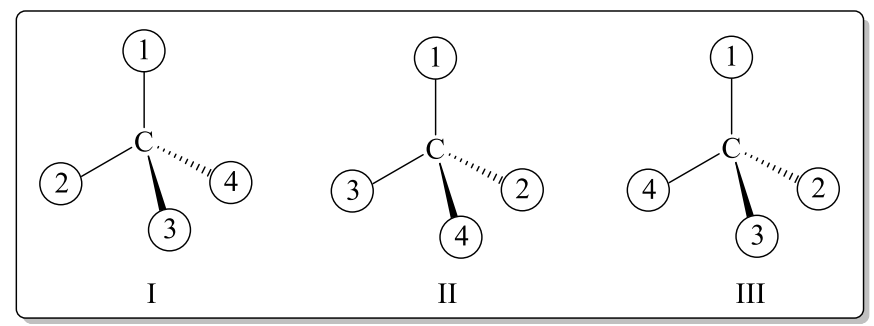




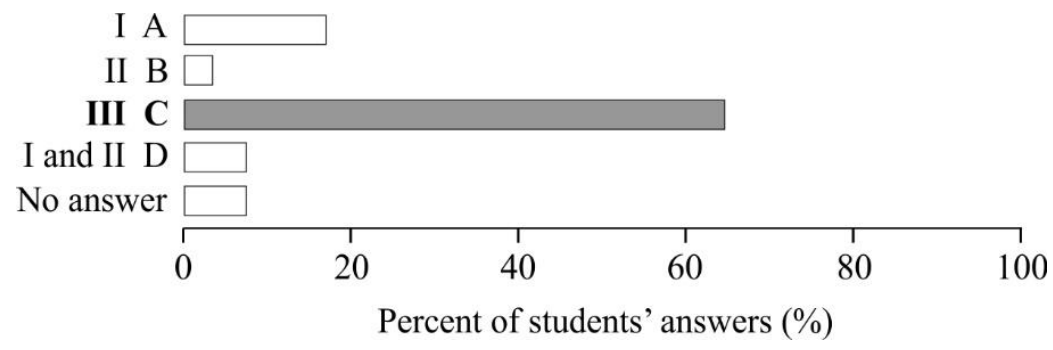

Figure 2. Results of questions 8 and 9. The correct answers are marked in bold.

Questions 8 and 9 were about $R / S$ nomenclature. So, they were directly related correct ranking of substituents. As can be seen from Figure 2, 89.29\% and $64.29 \%$ of students assigned the configuration of stereogenic center correctly in these questions. In addition, for Q8, although 7.14\% of the students determined ranking of substituents correctly, they assigned the configuration as wrong.

Questions 10 and 11 were about identifying an enantiomer pair. For Q10 only $46.43 \%$ of prospective teachers determined an enantiomer pair correctly. This ratio was lowered to $17.86 \%$ for Q11. It is clearly seen in these questions, students have problems to realize different drawings of the same molecule. Some students chose the wrong answers because they didn't check whether the molecule was chiral or not first.

As can be seen from the results for Q12, an important part of the students $(39.3 \%)$ had a misconception that boiling point could be different for compounds that were enantiomers of each other. Most of the prospective chemistry teachers identified the diastereomer pair correctly given in Q13. But, about half of them had problems about physical properties of diastereomers (Q14).

Q15. What is the relationship between the two compounds shown below?

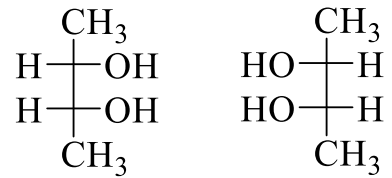

Identical. A

Enantiomers. B

Diastereomers. $\mathrm{C}$

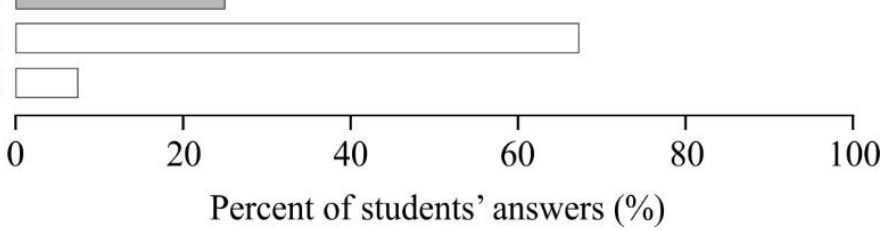

Figure 3. Results of question 15. The correct answer is marked in bold.

As shown in Figure 3, only 25\% of students recognized the different drawings of the meso compound given in Q15. Interestingly, $67.86 \%$ of the students evaluated these compounds as enantiomers. It is clear that these students mainly concentrate on the mirror images instead checking the whole molecule first. $7.14 \%$ of the students classified these compounds as diastereomers. So, totally $75 \%$ of chemistry teacher candidates gave scientifically unacceptable responses to this question.

Q16. Which of the following can rotate plane-polarized light?

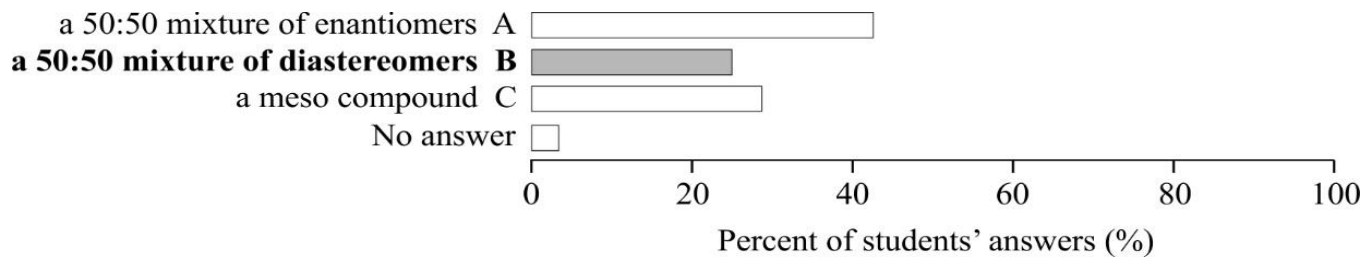

Figure 4. Results of question 16. The correct answer is marked in bold.

The next two questions (Q16 and 17) were about optical activity. From the results shown in Figure 4, only $25 \%$ of the students were successfully recognized the relationship between structure and optical activity. $42.86 \%$ of the candidates had a misconception that a racemic mixture could rotate plane-polarized light. In addition, $28.57 \%$ of the students thought that a meso compound would be optically active. 
Q17 was about which direction did (S)-2-hexanol rotate plane-polarized light. 42.86\% of the students answered this question correctly but $57.14 \%$ of them had misconceptions because it was not possible to predict which direction a particular enantiomer [either $(R)$ or $(S)$ ] would rotate the plane of polarized light. It was also observed that students had misconceptions about the relation between configuration and the sign of the specific rotation (dextrorotatory or levorotatory).

Last three questions of SCI were about projections. Q18 tested the ability of prospective teachers' ability to recognise a chiral molecule given as a Newman projection. The results revealed that more than half of the students had problems about converting a Newman projection to a perspective or sawhorse formula. So, they missed that the compound didn't have a carbon atom with four different substituents. Prospective chemistry teachers had also misconceptions related to Fischer projections. More than half of the candidates were unable to determine the orientation of substituents in Fischer projection correctly (Q19 and Q20).

\section{Conclusions}

The results of this study showed that although prospective chemistry teachers took theoretical instruction on stereochemistry, their conceptual structures of "stereochemistry" were not academically sufficient. In addition, students were found to have misconceptions about the basics of stereochemistry. These misconceptions were found to be parallel to the literature. Some of them were summarized as follow:

- A molecule is classified as chiral if it had an atom with four different substituents.

- According to Cahn-Ingold-Prelog rules, ranking of the substituents was based on electronegativity or size.

- When assigning configuration of a stereogenic centers, provided that the group of lowest priority is pointing directly back, a curved arrow drawn from the highest to second-highest to third-highest priority substituent is clockwise and the chirality center has $S$ configuration.

- Boiling points of enantiomers are different.

- Boiling points of diastereomers are the same.

- A racemic mixture can rotate plane-polarized light.

- A meso compound can rotate plane-polarized light.

- Just looking configuration of a compound, it is possible to predict the direction of plane-polarized light.

The findings showed that the cognitive structures of chemistry teacher candidates for "stereochemistry" needs to be improved more consciously and purposefully. According to the results of this study, the following suggestions can be given:

- Since the problems that students have about stereochemistry derives from interconverting structural representations, more attention should be given to this topic especially in General Chemistry II and Organic Chemistry I courses.

- Molecular models should be used more effectively in the courses. Open source software packages for molecular modelling and computational chemistry (Pirhadi, Sunseri \& Koes, 2016) could be used for this purpose.

- Laboratory experiments about stereochemistry utilizing molecular models can be placed to the curriculum. Several books about general, organic and biochemistry laboratory experiments and laboratory manuals could be used for this purpose.

\section{References}

Anderson, T. L., \& Bodner, G. M. (2008). What can we do about Parker? A case study of a good student who didn't get organic chemistry. Chemistry Education Research and Practice, 9, 93-101. https://doi.org/10.1039/B806223B

Barta, N. S., \& Stille, J. R. (1994). Grasping the concepts of stereochemistry. J. Chem. Educ., 71(1), 853-855. https://doi.org/10.1021/ed071p20

Black, K. A. (1990). Flow chart determination of isomeric relationship. J. Chem. Educ., 67(2), 141-142. https://doi.org/10.1021/ed067p141

Bruice, P. Y. (2016). Organic Chemistry, Eight Edition. Upper Saddle River, NJ: Pearson Education, Inc.

Bryan L. C. H. (2007). Identifying students' misconceptions in 'a-level' organic chemistry, Singapore: Innova Junior College.

Burrmann, N. J., \& Moore, J. W. (2013). Development of a Web-Based, Student-Centered Stereochemistry Tutorial. J. Chem. Educ., 90(12), 1622-1625. https://doi.org/10.1021/ed300744s 
Burrmann, N. J., \& Moore, J. W. (2015). Implementation and Student Testing of a Web-Based, Student Centered Stereochemistry Tutorial. J. Chem. Educ., 92(7), 1178-1187. https://doi.org/10.1021/ed500635d

Canpolat, N. (2006). Turkish Undergraduates' Misconceptions of Evaporation, Evaporation Rate, and Vapour Pressure, International Journal of Science Education, 28(15), 1757-1770. https://doi.org/10.1080/09500690600779957

Colley, K. E. (2006). Understanding ecology content knowledge and acquiring science process skills through project-based science instruction. Science Activities: Classroom Projects and Curriculum Ideas, 43(1), 26-33. https://doi.org/10.3200/SATS.43.1.26-33

da Silva Junior, J. N., Sousa Lima, M. A., Xerez Moreira, J. V., Oliveira Alexandre, F. S., de Almeida, D. M., de Oliveira, M. C. F., \& Melo Leite Junior, A. J. (2017). Stereogame: An Interactive Computer Game That Engages Students in Reviewing Stereochemistry Concepts. J. Chem. Educ., 94, 248-250. https://doi.org/10.1021/acs.jchemed.6b00475

Domin, D. S., Al-Masum, M., \& Mensah, J. (2008). Students' categorizations of organic compounds. Chemistry Education Research and Practice, 9, 114-121. https://doi.org/10.1039/B806226A

Eliel, E. L. (1985). The R/S system: A method for assignment and some recent modifications. J. Chem. Educ., 62(3). 223-224. https://doi.org/10.1021/ed062p223

Ferguson, R., \& Bodner, G. M. (2008). Making sense of the arrow-pushing formalism among chemistry majors enrolled in Organic Chemistry. Chemistry Education Research and Practice, 9, 102-113. https://doi.org/10.1039/B806225K

Gercek, C. (2018). Prospective teachers' cognitive structures concerning protein synthesis and their degree of understanding. Journal of Baltic Science Education, 18, 19-30.

Hazel, E., \& Prosser, M. (1994). First-year university students' understanding of photosynthesis, their study strategies and learning context. The American Biology Teacher, 56, 274-279. https://doi.org/10.2307/4449820

Knowles, T. H. (2017). Using eye-tracking and molecular modeling to explore students' strategies for solving organic stereochemical problems. Doctor of Philosophy Dissertation, The Graduate School of University of Northern Colorado, Greeley, Colorado.

Köse, S. (2008). Diagnosing Student Misconceptions: Using Drawings as a Research Method. World Applied Sciences Journal, 3(2), 283-293.

Krylova, I. (1997). Investigation of causes of differences in student performance on the topics of stereochemsitry and reaction mechanisms in an undergraduate organic chemistry course. ProQuest Dissertations and Theses.

Kurbanoglu, N. I., Taskesenligil, Y., \& Sozbilir, M. (2006). Programmed instruction revisited: a study on teaching stereochemistry. Chemistry Education Research and Practice, 7(1), 13-21. https://doi.org/10.1039/B5RP90012C

Leontyev, A. (2015). Development of a Stereochemistry Concept Inventory. Doctor of Philosophy Dissertation, The Graduate School of University of Northern Colorado, Greeley, Colorado.

Lyon, G. L. (1999). College students' understanding of stereochemistry: Difficulties in learning and critical junctures. Louisiana State University.

Mdachi, S. J. M. (2012). Giving Thought to Students' Alternative Conceptions in Stereochemistry: One Teacher's Basis for Pedagogical Content Knowledge Improvement. Journal of Turkish Science Education, 9(4), 22-34.

Michael, J. (2002). Misconceptions-what students think they know. Adv. Physiol. Educ., 26, 5-6. https://doi.org/10.1152/advan.00047.2001

Milenkovic, D. D., Hrin, T. N., Segedinac, M. D., \& Horvat, S. (2016). Development of a Three-Tier Test as a Valid Diagnostic Tool for Identification of Misconceptions Related to Carbohydrates. J. Chem. Educ., 93, 1514-1520. https://doi.org/10.1021/acs.jchemed.6b00261

Mohamed-Salah, B., \& Alain, D. (2016). To what degree does handling concrete molecular models promote the ability to translate and coordinate between 2D and 3D molecular structure representations? A case study with Algerian students. Chem. Educ. Res. Pract., 17, 862-877. https://doi.org/10.1039/C5RP00180C

Nakhleh, M. (1992). Why Some Students Don’t Learn Chemistry: Chemical Misconceptions. J. Chem. Educ., 69 (3), 191-196. https://doi.org/10.1021/ed069p191

Pavlinic, S., Buckley, P., Davies, J., \& Wright, T. (2001). Computing in Stereochemistry - 2D or 3D Representations?. In: Behrendt H. et al. (eds) Research in Science Education - Past, Present, and Future. Springer, Dordrecht.

Pirhadi, S., Sunseri, J., \& Koes, D. R. (2016). Open source molecular modeling. Journal of Molecular Graphics and 
Modelling, 69, 127-143. https://doi.org/10.1016/j.jmgm.2016.07.008

Rushton, G. T., Hardy, R. C., Gwaltney, K. P., \& Lewis, S. E. (2008). Alternative conceptions of Organic Chemistry topics among fourth year chemistry students. Chemistry Education Research and Practice, 9, 122-130. https://doi.org/10.1039/B806228P

Schmidt, H. J. (1997). Students' misconceptions-looking for a pattern. Sci. Educ., 81, 123-135. https://doi.org/10.1002/(SICI)1098-237X(199704)81:2<123::AID-SCE1>3.0.CO;2-H

Şendur, G. (2012). Prospective science teachers' misconceptions in organic chemistry: The case of alkenes. Journal of Turkish Science Education, 9, 186-190.

Şendur, G., Toprak, M., \& Pekmez, S. E. (2011). How can secondary school students perceive chemical equilibrium? NWSA, 6(2), 1512-1531.

Stull, A. T., Gainer, M., Padalkar, S., \& Hegarty, M. (2016). Promoting Representational Competence with Molecular Models in Organic Chemistry. J. Chem. Educ., 93(6), 994-1001. https://doi.org/10.1021/acs.jchemed.6b00194

Taagepera, M., \& Noori, S. (2000). Mapping students' thinking patterns in learning Organic Chemistry by the use of Knowledge Space Theory, J. Chem. Educ., 77(9), 1224-1229. https://doi.org/10.1021/ed077p1224

Taber, K. (2002). Chemical misconceptions-prevention, diognosis and cure: Volume 1-Theoretical background, London: Royal Society of Chemistry.

Taber, K. S. (2000). Multiple frameworks? Evidence of manifold conceptions in individual cognitive structure. International Journal of Science Education, 22(4), 399-417. https://doi.org/10.1080/095006900289813

Tuckey, H., Selvaratnam, M., \& Bradley, J. (1991). Identification and rectification of student difficulties concerning three-dimensional structures, rotation and reflection. J. Chem. Educ., 68(6), 460-464. https://doi.org/10.1021/ed068p460

Vrabec, M., \& Proksa, M. (2016). Identifying Misconceptions Related to Chemical Bonding Concepts in the Slovak School System Using the Bonding Representations Inventory as a Diagnostic Tool. J. Chem. Educ., 93, 1364-1370. https://doi.org/10.1021/acs.jchemed.5b00953

Woolley, J. S., Deal, A. M., Green, J., Hathenbruck, F., Kurtz, S. A., Park, T. K. H., ... Jensen, J. L. (2018). Undergraduate students demonstrate common false scientificreasoning strategies. Thinking Skills and Creativity, 27, 101-113. https://doi.org/10.1016/j.tsc.2017.12.004

\section{Copyrights}

Copyright for this article is retained by the author(s), with first publication rights granted to the journal.

This is an open-access article distributed under the terms and conditions of the Creative Commons Attribution license which permits unrestricted use, distribution, and reproduction in any medium, provided the original work is properly cited. 